\title{
MENINGKATKAN KETERAMPILAN BERBICARA SISWA MATAPELAJARAN BAHASA INDONESIA DENGAN MENGGUNAKAN MODEL TIME TOKEN DI KELAS X SMA NEGERI 5 MEDAN
}

\author{
BETI ROHAINI \\ SMA Negeri 5 Medan \\ Email : betirohaini@gmail.com
}

\begin{abstract}
ABSTRAK
Penelitian ini adalah Penelitian Tindakan Kelas yang bertujuan meningkatkan keterampilan berbicara siswa dengan menggunakan model Time Token. Subjek dalam penelitian ini adalah siswa kelas X SMA Negeri 5 Medan yang berjumlah 35 orang siswa. Alat yang digunakan dalam pengumpulan data adalah observasi yang dilakukan pada saat pembelajaran berlangsung guna mendapatkan keterampilan berbicara siswa pokok bahasan teks anekdot. Penelitian ini terdiri dari 2 siklus, yaitu siklus I dan II. Setiap siklus terdiri dari 4 tahap yaitu tahap perencanaan, pelaksanaan, pengamatan, dan refleksi. Berdasarkan hasil penelitian menunjukkan bahwa pada observasi awal diperolah nilai rata-rata sebagai berikut : Pada siklus I pertemuan 1 terdapat 9 orang siswa (26\%) yang dinyatakan terampil berbicara, 26 orang siswa (74\%) yang kurang terampil berbicara. Pengamatan yang dilakukan terhadap guru menunjukkan nilai 65 dan pengamatan terhadap aktivitas siswa diperoleh nilai 56,87. Pada siklus 1 pertemuan 2 terdapat 18 orang siswa $(51 \%)$ yang dinyatakan terampil berbicara, 17 orang siswa (49\%) yang kurang terampil berbicara. Pengamatan yang dilakukan terhadap guru menunjukkan nilai 67,5 dan pengamatan terhadapak aktivitas siswa diperoleh nilai 65,50. Pada siklus II pertemuan 1 terdapat 29 orang siswa (83\%) yang dinyatakan terampil berbicara, 6 orang siswa (17\%) yang kurang terampil berbicara. Pengamatan yang dilakukan terhadap aktivitas guru menunjukkan nilai 75 dan aktivitas siswa menunjukkan nilai 73,87. Pada siklus II pertemuan 2 terdapat 35 orang siswa (100\%) yang dinyatakan terampil berbicara . Dan dari hasil pengamatan aktivitas guru menunjukkan nilai 85 , dan aktivitas siswa menunjukkan nilai 85,75 . Berdasarkan hasil penelitian ini, dapat disimpulkan bahwa dengan menggunakan model pembelajaran Time Token dapat meningkatkan keterampilan berbicara siswa pada mata pelajaran Bahasa Indonesia pada materi pokok teks anekdot di kelas X SMA Negeri 5 Medan.
\end{abstract}

Kata Kunci : Keterampilan, berbicara, bahasa Indonesia, model Time Token

\section{ABSTRACT}

This research is a Classroom Action Research which aims to improve students' speaking skills by using the Time Token model. The subjects in this study were students of class X SMA Negeri 5 Medan who collected 35 students. The tool used in data collection is observations made during the learning process in order to get the speaking skills of the main students of anecdotal language texts. This study consisted of 2 cycles, namely cycles I and II. Each cycle consists of 4 stages, namely the stages of planning, implementation, observation, and reflection. Based on the research, it was shown that the initial observations obtained the following average values: In the first cycle of meeting 1 there were 9 people (26\%) who were skilled at speaking, 26 people (74\%) were less skilled at speaking. conducted on the teacher showed 65 and observations of the activities obtained 56.87. In cycle 1 meeting 2 there were 18 students $(51 \%)$ who were declared skilled at speaking, 17 people (49\%) were less skilled at speaking. conducted on the teacher showed a value of 67.5 and observations of activities obtained from the value of 65.50. In the second cycle of meeting 1 there were 29 students $(83 \%)$ who were skilled at speaking, 6 people $(17 \%)$ were less skilled at speaking. which was carried out on teacher activities showed a value of 75 and student activities showed a value of 73.87 . In the second cycle of meeting 2 there were 33 students (100\%) who were declared skilled in speaking. And the results of observations of teacher activities show a value of 85, and student activities show a value of 85.75. Based on the results of this study, it can be said that using the Time Token 
learning model can improve students' speaking skills in Indonesian subjects on the subject matter of anecdotal texts in class X SMA Negeri 5 Medan.

Keywords: Skills, speaking, Indonesian language, Time Token model

\section{PENDAHULUAN}

Dalam pembelajaran bahasa Indonesia, siswa harus menguasai empat komponen keterampilan berbahasa yaitu: keterampilan menyimak (listening skiils), keterampilan berbicara (speaking skiils), keterampilan membaca (reading skiils), keterampilan menulis (writing skiils), Dari ke empat keterampilan tersebut, maka keterampilan berbicara harus lebih dikuasai oleh setiap siswa karena keterampilan berbicara merupakan keterampilan dasar yang bagi setiap manusia untuk berkomunikasi. Semakin siswa terampil berbicara maka semakin lancer pula komunikasi yang dilakukannya

Menurut Brown (2007:125) indikator dari keterampilan berbicara siswa adalah sebagai berikut: 1) mengemukakan pendapat yang meliputi: pandangan siswa ketika berbicara, gerakgerik siswa ketika berbicara, keberanian siswa ketika berbicara, 2) mengemukakan gagasan yang meliputi: penguasaan topik/ materi dalam pembelajaran, ragam bahasa yang diucapkan ketika mengemukakan gagasan, pengucapan vokal dan konsonan, dan 3) mengemikakan perasaan yang meliputi: berbicara dengan mengeluarkan suara yang nyaring, pengucapan sesuai dengan tekanan nada dan irama, dan variasi dalam pemilihan dan ketepatan kata.

Di samping itu menurut Reber dalam Syah (2010:117) berpendapat bahwa "Keterampilan adalah kemampuan melakukan pola-pola tingkah laku yang kompleks dan tersusun rapi secara mulus dan sesuai dengan keadaan untuk mencapai hasil tertentu". Dalam hal ini keterampilan bukan hanya meliputi gerakan motorik melainkan juga pemanfaatan fungsi mental yang bersifat kognitif. Maksudnya disini adalah kegiatan mempengaruhi atau mendaya gunakan orang lain juga dianggap sebagai orang yang terampil.

Menurut Tantawi (2019 : 113) bahwa Keterampilan berbicara adalah kemampuan sesorang untuk mengungkapkan pikiran secara langsung atau tidak langsung. Berbicara secara langsung adalah pembicaraa berhadapan langsung dengan pendengarnya, sedangkan berbicara tidak langsung pembicara tidak berhadapan dengan pendengarnya, misalnya siaran radio atau televisi.

Keterampilan berbicara adalah suatu kemampuan untuk mengungkapkan ide atau gagasan, pikiran, pengalaman, serta pendapatnya dengan baik dan benar. Semua manusia normal berbicara tetapi tidak semua memiliki keterampilan dalam menyampaikan idenya dengan baik dan benar, maka dari kecil hingga menginjakkan kaki dalam dunia pendidikan keterampilan berbicara harus lebih ditentukan pembinaannya pada setiap siswa. disamping membaca, menulis dan menghitung dengan seringnya anak mengungkapkannya hingga terampil dalam berbicara.

Berdasarkan pengamatan peneliti di dalam kegiatan pembelajaran ditemukan beberapa fakta terhadap kemampuan siswa dalam keterampilan berbicara meliputi : (1) siswa kurang mampu melafalkan bunyi bahasa dengan benar, (2) keterampilan intonasi atau naik turunnya suara saat berbicara, (3) susunan kalimatnya tidak sesuai atau tidak tepat dengan topik pembelajaran, (4) gerak-gerik dan mimik siswa tidak sesuai dengan apa yang sedang dibicarakan, (5) siswa kurang mampu berkomunikasi dalam mengungkapkan ide atau pendapatnya.

Karena siswa kurang mampu melafalkan bunyi bahasa dengan benar maka siswa banyak yang diam tanpa mengungkapkan pendapatnya, mereka terlihat takut atau ragu-ragu. Sebahagian kecil ada yang berani mengemukakan pendapatnya tapi belum menggunakan kosa kata yang benar serta cara berbicara mereka kurang maksimal atau belum dapat disebut dengan terampil dalam berbicara, hal itu disebabkan oleh kurangnya pendekatan dan perhatian guru terhadap siswa saat pembelajaran dilaksanakan. Ini dapat dilihat dari, (1) guru belum memahami sifat masing-masing siswa, (2) pembelajaran sering dilanjutkan tanpa memperhatikan apakah siswa sudah benar-benar paham atau tidak. 
Hal ini sangat erat hubungannya dengan penggunaan metode ataupun model pembelajaran yang digunakan oleh guru. Model pembelajaran yang tidak bervariasi dan kurang menarik minat belajar siswa maka siswa tidak termotivasi untuk belajar dan siswa juga terlihat pasif tanpa mengajak siswa untuk berpikir kritis. Disisi lain, guru juga tidak berusaha memotivasi siswa yang pasif untuk berbicara dan mengemukakan pendapat sesuai dengan apa yang ada dalam pikirannya, sehingga tingkat keterampilan berbicara siswa dalam menyampaikan ide atau pendapat tidak bertambah bahkan semakin berkurang. Selain itu guru sering melawatkan materi pembelajaran walaupun siswa belum menyimak pembelajaran dengan baik dan benar sehingga siswa tidak tertarik untuk mengetahui apa materi yang sedang diajarkan oleh guru di dalam kelas.

Salah satu model pembelajaran yang dapat digunakan dalam pembelajaran Bahasa Indonesia adalah dengan menerapkan model pembelajaran Time Token. Istarani (2012:194) "Model pembelajaran Time Token pengaturan waktu berbicara dan pemberian kesempatan untuk berbicara kepada masing-masing siswa akan mewujudkan keteraturan siswa untuk berbicara."

Hal ini menjelaskan bahwa pembelajaran harus dikemas jadi proses "Time Token" bukan "diam sama sekali atau hanya menerima" pengetahuan. Dalam proses pembelajaran, siswa membangun sendiri pengetahuan mereka melalui keterlibatan aktif dalam proses belajar mengajar. Siswalah yang seharusnya menjadi pusat kegiatan bukan guru. Untuk itu tugas guru adalah memfasilitasi proses berlangsungnya pembelajaran, Suprijono (2009:16). Model pembelajaran Time Token ini membantu siswa untuk terbiasa mengemukakan pendapat atau komentarnya di depan orang banyak, dimana siswa bergerak aktif untuk menyelesaikan atau mencari tahu sendiri tentang kejadian, peristiwa, kegiatan atau masalah yang telah dipaparkan guru terlebih dahulu di depan kelas.

Menurut Suyatno (2009:76) Model pembelajaran Time Token digunakan untuk melatih dan mengembangkan keterampilan sosial agar siswa tidak mendominasi pembicaraan". Suprijono (2009: 133) menyatakan bahwa: Alur pelaksanaan model pembelajaran time token dimana guru memberi sejumlah kupon berbicara dengan waktu \pm 30 detik per kupon pada tiap siswa. Sebelum berbicara, siswa menyerahkan kupon terlebih dahulu pada guru. Setiap tampil berbicara satu kupon. Siswa dapat tampil lagi setelah bergiliran dengan siswa lainnya. Siswa yang telah habis kuponnya tak boleh bicara lagi. Siswa yang masih memegang kupon harus bicara sampai semua kuponnya habis.

Sedangkan Menurut Miftahul huda (Huda, 2014:239-240) menyatakan bahwa: Model pembelajaran Time Token merupakan salah satu contoh kecil dari penerapan pembelajaran demokratis di sekolah. Proses pembelajaran yang demokratis adalah proses belajar yang menempatkan siswa sebagai subjek. Sepanjang proses belajar, aktivitas siswa menjadi titik perhatian utama. Dengan kata lain mereka selalu dilibatkan secara aktif. Guru berperan mengajak siswa mencari solusi bersama terhadap permasalahan yang ditemui. Model ini digunakan untuk melatih dan mengembangkan keterampilan sosial agar siswa tidak mendominasi pembicaraan atau diam sama sekali. Guru memberi sejumlah kupon berbicara dengan waktu \pm 30 detik per kupon pada tiap siswa. Sebelum berbicara, siswa menyerahkan kupon terlebih dahulu pada guru. Satu kupon adalah untuk satu kesempatan berbicara. Siswa dapat tampil lagi setelah bergiliran dengan siswa lainnya. Siswa yang telah habis kuponnya tak boleh bicara lagi. Siswa yang masih memegang kupon harus bicara sampai semua kuponnya habis.

Berdasarkan uraian di atas maka dapat disimpulkan bahwa Model pembelajaran Time Token merupakan salah satu contoh kecil dari penerapan pembelajaran demokratis di sekolah, dimana digunakan untuk mengajarkan keterampilan sosial serta melibatkan siswa secara aktif dalam proses belajar mengajar sehingga dapat menghindari siswa mendominasi pembicaraan atau siswa diam sama sekali.

Menurut Huda (2014:240), adapun langkah-langkah dari model pembelajaran Time Token ini adalah sebagai berikut 
a. Guru menjelaskan tujuan pembelajaran atau kompetensi dasar.

b. Guru mengkondisikan kelas untuk melaksanakan diskusi klasikal

c. Guru memberi tugas pada siswa.

d. Guru memberi sejumlah kupon berbicara dengan waktu \pm 30 detik per kupon pada tiap siswa.

e. Guru meminta siswa menyerahkan kupon terlebih dahulu sebelum berbicara atau memberi komentar. Satu Kupon untuk satu kesempatan berbicara. Siswa dapat tampil lagi setelah bergiliran dengan siswa lainnya. Siswa yang telah habis kuponnya tak boleh bicara lagi. Siswa yang masih memegang kupon harus bicara sampai semua kuponnya habis. Demikian seterusnya hingga semua anak berbicara.

f. Guru memberi sejumlah nilai berdasarkan waktu yang digunakan tiap siswa dalam berbicara

Pemilihan materi yang sesuai untuk model pembelajaran Time token adalah materi yang lebih menekankan pada penyampaian pendapat siswa dalam berlangsungnya pembelajaran. Hal ini dikarenakan model pembelajaran ini lebih menekankan pada keaktifan siswa dalam mengutarakan pendapatnya mengenai suatu masalah yang muncul. Oleh sebab itu dalam penelitian ini dipilihlah materi teks anekdot karena pada materi ini siswa dituntut untuk dapat menyampaikan anekdot yang dia ketahui. Pemahaman tentang materi oleh siswa dalam model ini sangat diutamakan terutama dalam bentuk diskusi yang kebanyakan pendapatnya harus memiliki dasar yang kuat untuk sebuah argumen. Model pembelajaran Time Token merupakan salah satu contoh kecil dari penerapan pembelajaran demokratis di sekolah, dimana digunakan untuk mengajarkan keterampilan sosial serta melibatkan siswa secara aktif dalam proses belajar mengajar sehingga dapat menghindari siswa mendominasi pembicaraan atau siswa diam sama sekali.

Berdasarkan permasalahan masih kurangnya keterampilan siswa dalam berbicara maka peneliti mencoba meggunakan metode Time Token untuk meningkatkan keterampilan siswa tersebut. Untuk itu dapat dirumuskan permasalahan yang akan diteliti adalah Apakah dengan menggunaan model pembelajaran Time Token dapat meningkatkan keterampilan berbicara siswa mata pelajaran Bahasa Indonesia khususnya pada materi pokok teks anekdot di Kelas X SMA Negeri 5 Medan. Dengan demikian tujuan dilakukannya penelitian ini adalah untuk meningkatkan keterampilan berbicara siswa mata pelajaran Bahasa Indonesia dengan menggunakan model pembelajaran Time Token pada materi pokok teks anekdot di Kelas X SMA Negeri 5 Medan. .

\section{METODE PENELITIAN}

Adapun jenis penelitian ini adalah penelitian tindakan kelas (classroom research action) yang pada pelaksanaanya menggunakan pendekatan kualitataif yang pada dasarnya memiliki fungsi sebagai inovasi terhadap proses pembelajaran khususnya pada pembelajaran Bahasa Indonesia agar dapat meningkatkan kemampuan berbicara siswa yang diperoleh melalui kemampuan siswa dalam mengungkapkan pendapat.

Penelitian ini dilaksanakan di kelas X SMA Negeri 5 Medan T.A 2019/2020. Penelitian ini dilaksanakan selama 3 bulan yaitu dari bulan Juli sampai bulan September dan pelaksanaannya tergambar pada siklus. Dimana siklus terdiri dari empat komponen yang dimulai dari kegiatan perencanaan sampai dengan refleksi.

Subjek dalam Penelitian Tindakan Kelas ini adalah siswa kelas X SMA Negeri 5 Medan, yang berjumlah 35 Siswa. Objek penelitian ini adalah meningkatkan keterampilan berbicara siswa kelas X dengan menggunakan Model pembelajaran Time Token.

Adapun yang menjadi operasional masing-masing variabel dalam penelitian ini adalah 
a) Keterampilan berbicara merupakan kemampuan mengemukakan gagasan-gagasan yang telah disusun pembicara untuk disampaikan kepada pendengar sehingga kegiatan komunikasi dapat berlangsung secara efektif.

b) Model pembelajaran Time Token yaitu suatu sistem pembelajaran yang menuntut siswa untuk menemukan pengetahuan sendiri dan mengembangkankannya sehingga pembelajaran dapat memberikan makna bagi siswa melalui pengalaman nyata.

Desain penelitian berbentuk Penelitian Tindakan Kelas ( PTK ), Seluruh tahapan yang dilakukan berbentuk siklus seperti pada Gambar di bawah ini :

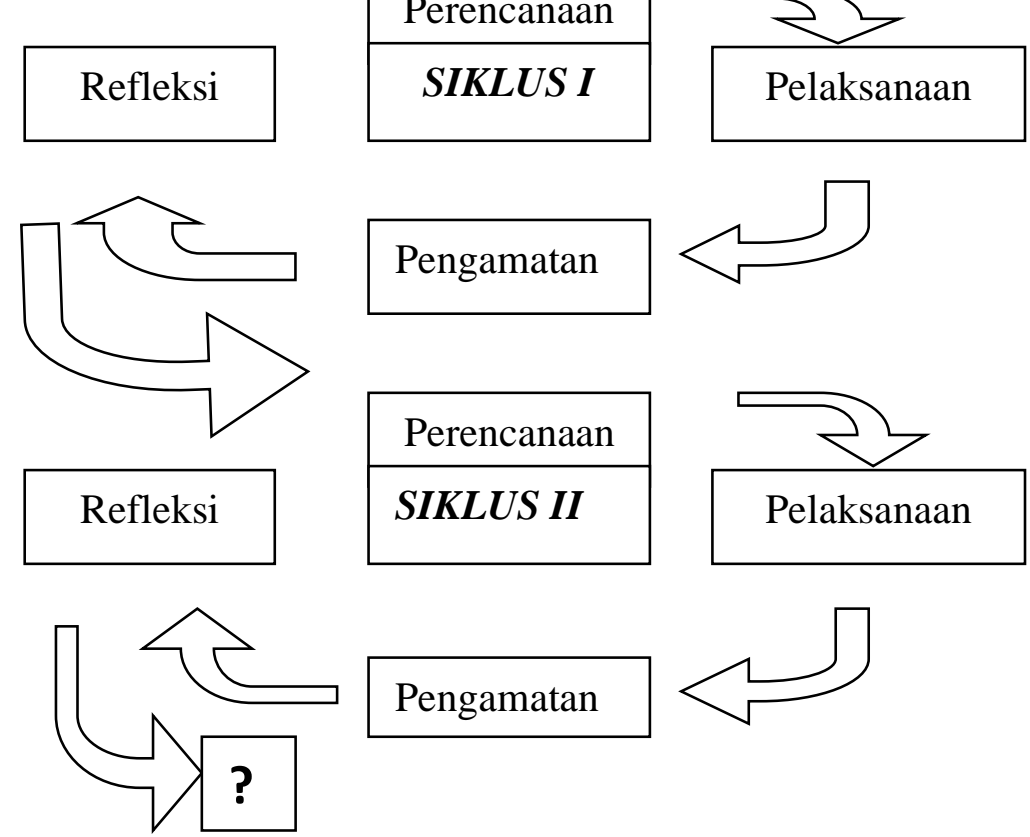

Gambar 1. Model penelitian tindakan kelas (PTK) Arikunto (2015:42)

Teknik Pengumpulan data dilakukan menggunakan lembar observasi tentang keterampilan siswa dalam berbicara, peneliti juga mengamati prilaku siswa selama proses pembelajaran. Pedoman observasi atau pengamatan ini diisi selama pembelajaran berlangsung dengan cara memberi tanda cek $(\sqrt{ })$ pada setiap aspek yang diamati sesuai dengan kategori ( keadaan dikelas), apakah termasuk sangat terampil, terampil,cukup terampil dan kurang terampil.

\section{HASIL PENELITIAN DAN PEMBAHASAN}

\section{Hasil Penelitian}

Siklus I berlangsung dengan jumlah siswa yang hadir 35 orang. Tindakan dilaksanan seperti pembelajaran biasa dengan tidak mengubah jadwal pembelajaran siswa. Pelaksanaan siklus I dilaksanakan selama 90 menit ( 2 x 45 menit) atau dua jam pelajaran.

Berdasarkan observasi awal yang dilakukan, dapat diketahui bahwa keterampilan berbicara siswa pada mata pelajaran Bahasa Inggris masih rendah. Hal ini bisa juga disebabkan beberapa faktor, yaitu dimana guru tidak menggunakan model yang tepat sesuai dengan materi pelajaran yang akan disampaikan. Oleh karena itu peneliti menggunakan model Pembelajaran Time Token untuk meningkatkan keterampilan berbicara siswa dengan Merespon percakapan lisan . Pada tahap ini, perencanaan tindakan yang dilakukan peneliti adalah sebagai berikut : menyiapkan Rencana Pelaksanaan Pembelajaran (RPP), menyiapkan bahan ajar, menyiapkan lembar penilaian indikator keterampilan berbicara siswa.

Adapun langkah-langkah pembelajaran yang disusun dalam RPP di desain dengan langkah-langkah pada model pembelajaran Time Token sebagai berikut. 


\section{a. Kegiatan Awal}

Setelah perencanaan disusun, maka dilakukan tindakan terhadap permasalahan yang terdapat di kelas tersebut. Tindakan yang akan dilakukan adalah dengan menggunakan model Time Token. Peneliti bertindak sebagai guru, sedangkan wali kelas X bertindak sebagai observer yang akan memberikan masukan dan kritikan yang berguna untuk peneliti ini dan tahap selanjutnya.

\section{b. Kegiatan inti}

1) Guru membagi siswa menjadi 10 kelompok, masing-masing kelompok berjumlah 3 dan 4 orang. setiap anggota kelompok memiliki kupon yang berbeda. Kupon ini merupakan tanggung jawab dari masing-masing individu bukan kelompok. Kelompok hanya teman untuk berbagi atau tukar pikiran saja.

2) Menjelaskan kepada siswa tentang aturan yang harus dipatuhi oleh masing-masing kelompok. Setiap kelompok akan membacakan teks anekdot yang telah disiapkan oleh guru.

3) Menjelaskan kepada siswa bagaimana cara siswa menanggapi atau memberikan komentar, yaitu salah satunya dengan mengarahkan pandangan kepada lawan bicaranya.

4) Meminta siswa untuk teks anekdot yang telah dibagikan dan memperhatikan gambar yang telah ditempelkan oleh guru di papan tulis.

5) Setelah siswa selesai cerita anekdot, Guru meminta siswa untuk memberikan komentar mengenai peristiwa yang terjadi di dalam cerita anekdot tersebut.

6) Setiap siswa diberi kesempatan untuk berbicara, sesuai dengan tuntutan kartu yang telah dibagikan guru pada kegiatan awal. Setiap siswa harus menghabiskan kartu yang ada pada mereka.

7) Sedangkan sanksi bagi siswa yang tidak bisa menghabiskan kartunya akan diberi kartu tambahan lagi, sehingga siswa termotivasi untuk menghabiskan kartu yang ada di tangannya.

c. Kegiatan akhir

1) Guru bersama siswa menyimpulkan materi tentang teks anekdot yang sudah dibacakan oleh siswa bahwa selain lucu cerita anekdot juga berisi kritik terhadap tingkah laku yang tidak baik.

2) Guru melakukan tanya jawab dengan siswa untuk mengetahui kesan yang dirasakan oleh siswa ketika belajar dengan menggunakan model Pembelajaran Time Token pada materi teks anekdot.

Dalam kegiatan observasi, observer (teman guru) melakukan pengamatan terhadap guru sebagai peneliti dengan menggunakan alat bantu berupa lembar observasi yang telah disediakan.Dari hasil observasi tersebut aktivitas guru belum mencapai hasil seperti yang diharapkan.

Selama proses pembelajaran berlangsung, peneliti melakukan pengamatan terhadap kegiatan pelaksanaan pembelajaran yang dilakukan dan mengamati keterampilan berbicara siswa berdasarkan format yang telah disiapkan. Dari hasil pengamatan kegiatan pelaksanaan pembelajarana yang dilakukan peneliti maka hasilnya dapat dilihat pada tabel berikut:

\section{Tabel 1.}

Deskripsi Hasil Observasi Siklus I Pertemuan 2 Keterampilan Berbicara Siswa Dalam Kategori

\begin{tabular}{|l|l|l|c|c|c|}
\hline No. & \multicolumn{1}{|c|}{ Kriteria } & \multicolumn{1}{|c|}{ Kategori } & $\begin{array}{c}\text { Tingkat } \\
\text { Penguasaan }\end{array}$ & $\begin{array}{c}\text { Jumlah } \\
\text { Siswa }\end{array}$ & Persentase \\
\hline 1. & Pandangan siswa ketika & Sangat Terampi & 4 & 3 & $9 \%$ \\
& berbicara & Terampil & 3 & 17 & $48 \%$ \\
& & Cukup Terampil & 2 & 12 & $20 \%$ \\
& & Kurang Terampil & 1 & 3 & $9 \%$ \\
\hline
\end{tabular}


Vol 1. No 2. November 2021, e-ISSN : 2807-1670 | p-ISSN : 2807-2316

\begin{tabular}{|c|c|c|c|c|c|}
\hline 2. & $\begin{array}{l}\text { Gerak-gerik mimik siswa } \\
\text { ketika berbicara }\end{array}$ & $\begin{array}{l}\text { Sangat Terampi } \\
\text { Terampil } \\
\text { Cukup Terampil } \\
\text { Kurang Terampil }\end{array}$ & $\begin{array}{l}4 \\
3 \\
2 \\
1\end{array}$ & $\begin{array}{c}2 \\
12 \\
16 \\
5\end{array}$ & $\begin{array}{c}6 \% \\
34 \% \\
46 \% \\
14 \%\end{array}$ \\
\hline 3. & $\begin{array}{l}\text { Keberanian siswa ketika } \\
\text { berbicara }\end{array}$ & $\begin{array}{l}\text { Sangat Terampi } \\
\text { Terampil } \\
\text { Cukup Terampil } \\
\text { Kurang Terampil }\end{array}$ & $\begin{array}{l}4 \\
3 \\
2 \\
1\end{array}$ & $\begin{array}{c}3 \\
12 \\
11 \\
9\end{array}$ & $\begin{array}{l}9 \% \\
34 \% \\
32 \% \\
26 \%\end{array}$ \\
\hline 4. & $\begin{array}{l}\text { Penguasaan topik dalam } \\
\text { pengajaran }\end{array}$ & $\begin{array}{l}\text { Sangat Terampi } \\
\text { Terampil } \\
\text { Cukup Terampil } \\
\text { Kurang Terampil }\end{array}$ & $\begin{array}{l}4 \\
3 \\
2 \\
1\end{array}$ & $\begin{array}{c}4 \\
12 \\
13 \\
6 \\
\end{array}$ & $\begin{array}{l}12 \% \\
34 \% \\
37 \% \\
17 \%\end{array}$ \\
\hline 5. & $\begin{array}{l}\text { Ragam bahasa yang } \\
\text { diucapkan ketika } \\
\text { mengemukakan gagasan }\end{array}$ & $\begin{array}{l}\text { Sangat Terampi } \\
\text { Terampil } \\
\text { Cukup Terampil } \\
\text { Kurang Terampil }\end{array}$ & $\begin{array}{l}4 \\
3 \\
2 \\
1\end{array}$ & $\begin{array}{c}2 \\
15 \\
14 \\
4\end{array}$ & $\begin{array}{l}6 \% \\
42 \% \\
40 \% \\
12 \% \\
\end{array}$ \\
\hline 6. & $\begin{array}{l}\text { Pengucapan vocal dan } \\
\text { konsonan }\end{array}$ & $\begin{array}{l}\text { Sangat Terampi } \\
\text { Terampil } \\
\text { Cukup Terampil } \\
\text { Kurang Terampil }\end{array}$ & $\begin{array}{l}4 \\
3 \\
2 \\
1\end{array}$ & $\begin{array}{cc} & 4 \\
& 10 \\
& 16 \\
5 & \\
\end{array}$ & $\begin{array}{l}12 \% \\
28 \% \\
46 \% \\
14 \% \\
\end{array}$ \\
\hline 7. & $\begin{array}{l}\text { Berbicara dengan } \\
\text { mengeluarkan suara yang } \\
\text { nyaring }\end{array}$ & $\begin{array}{l}\text { Sangat Terampi } \\
\text { Terampil } \\
\text { Cukup Terampil } \\
\text { Kurang Terampil }\end{array}$ & $\begin{array}{l}4 \\
3 \\
2 \\
1\end{array}$ & $\begin{array}{c}4 \\
15 \\
13 \\
3\end{array}$ & $\begin{array}{c}12 \% \\
42 \% \\
37 \% \\
9 \% \\
\end{array}$ \\
\hline 8. & $\begin{array}{l}\text { Pengucapan sesuai dengan } \\
\text { tekanan nada dan irama }\end{array}$ & $\begin{array}{l}\text { Sangat Terampi } \\
\text { Terampil } \\
\text { Cukup Terampil } \\
\text { Kurang Terampil }\end{array}$ & $\begin{array}{l}4 \\
3 \\
2 \\
1\end{array}$ & $\begin{array}{c}2 \\
10 \\
18 \\
5\end{array}$ & $\begin{array}{c}6 \% \\
28 \% \\
52 \% \\
14 \% \\
\end{array}$ \\
\hline \multicolumn{3}{|c|}{ Jumlah } & & 35 & $100 \%$ \\
\hline
\end{tabular}

Refleksi Siklus I adalah sebagai berikut : Proses data yang diperoleh dari kerja sama antara peneliti dan guru bahasa Indonesia kelas X (observer) ternyata keterampilan berbicara siswa masih rendah pada siklus I pertemuan 1 dan 2. Pada pertemuan 1 dari 35 orang siswa hanya 9 orang siswa (30\%) yang terampil berbicara dengan rata-rata skor total yang diperoleh 56,66 dan pada siklus 1 pertemuan 2 sebanyak 18 orang siswa (51\%) yang terampil berbicara dengan rata-rata skor total 65,08. Berdasarkan persentase keterampilan berbicara pada siklus I pertemuan 2 sebesar $48 \%$, dapat disimpulkan bahwa peringkat keterampilan siswa termasuk pada kriteria penilaian kurang terampil, sedangkan observasi yang dilakukan terhadap guru diperoleh nilai rata-rata 65,90. Untuk mengetahui keterampilan berbicara siswa secara klasikal pada siklus I dapat di lihat dari tabel berikut:

Tabel 2

Keterampilan Berbicara Siswa Secara Klasikal Pada Siklus I

\begin{tabular}{|c|l|c|c|c|}
\hline No & \multicolumn{1}{|c|}{ Kategori } & $\begin{array}{c}\text { Siklus } 1 \text { pertemuan } \\
1\end{array}$ & $\begin{array}{c}\text { Siklus 1 } \\
\text { pertemuan 2 }\end{array}$ & $\begin{array}{c}\text { Jumlah } \\
\text { Siswa }\end{array}$ \\
\hline 1 & Siswa Terampil & $\mathbf{9}$ & $\mathbf{1 8}$ & \\
\hline 2 & Siswa Kurang Terampil & $\mathbf{2 6}$ & $\mathbf{1 7}$ & \\
\cline { 1 - 3 } Persentase Keterampilan & $\frac{\mathbf{9}}{\mathbf{3 5}} \boldsymbol{x} \mathbf{1 0 0} \%$ & $\frac{\mathbf{1 8}}{\mathbf{3 5}} \boldsymbol{x} \mathbf{1 0 0} \%=\mathbf{5 1 \%}$ & \\
Berbicara Siswa: $\mathrm{P}=\frac{\boldsymbol{f}}{\boldsymbol{n}} \boldsymbol{x} \mathbf{1 0 0} \%$ & $\mathbf{3 0} \%$ & & \\
\hline
\end{tabular}

Berdasarkan tabel di atas menunjukkan bahwa jumlah siswa yang terampil berbicara pada pertemuan 1 adalah 9 orang siswa dengan persentase 30\% dan jumlah siswa yang kurang 
terampil adalah 26 orang siswa dengan persentase $70 \%$, sedangkan pada pertemuan ke 2 siswa yang terampil berbicara mengalami peningkatan. Siswa yang terampil berbicara berjumlah 11 orang siswa dengan persentase 51\% dan siswa yang kurang terampil berbicara adalah 18 orang siswa dengan persentase $49 \%$. Oleh karena itu, peneliti merasa perlu melakukan perbaikan pada pertemuan siklus 2 untuk meningkatkan keterampilan berbicara siswa yang diharapkan akan berdampak baik terhadap hasil belajar pada materi pokok Merespon percakapan lisan .

Adapun hal-hal yang perlu diperbaiki pada pelaksanaan siklus II yakni: meningkatkan keterlibatan siswa dalam proses pembelajaran, meningkatkan keterampilan berbicara siswa dengan memberikan pertanyaan maupun menjawab pertanyaan, dan memotivasi siswa agar lebih aktif dalam pembelajaran.

Deskripsi Hasil Penelitian Siklus II. Siklus II berlangsung pada dengan jumlah siswa yang hadir 35 orang. Tindakan dilaksanan seperti pembelajaran biasa dengan tidak mengubah jadwal pembelajaran siswa. Pelaksanaan siklus II dilaksanakan selama 90 menit ( 2 x 45 menit) atau dua jam pelajaran. Siklus II berlangsung pada dengan jumlah siswa yang hadir 25 orang. Tindakan dilaksanan seperti pembelajaran biasa dengan tidak mengubah jadual pembelajaran siswa. Pelaksanaan siklus II dilaksanakan selama 70 menit atau dua jam pelajaran.

Siklus ini merupakan lanjutan dari kegiatan siklus I yang belum maksimal. Pada tahap perencanaan ini sama dengan siklus I tetapi pembelajaran dilakukan dengan memperbaiki kekurangan yang telah ditemukan pada siklus I, diaman pada tahap ini peneliti lebih meningkatkan keterampilan siswa dengan memberikan motivasi dan arahan agar lebih aktif dalam proses belajar mengajar.

Kegiatan yang dilakukan peneliti pada siklus II yaitu adalah 1) mengembangkan materi ajar dalam bentuk Rencana Pelaksanaan Pembelajaran, 2) melaksanakan pembelajaran dengan menjelaskan tentang materi tentang naskah drama, 3) membuat kelompok belajar siswa 4) memberikan kesempatan yang sama bagi setiap siswa untuk menyatakan pendapatnya dengan bebas tanpa ada tekanan, 4) mendekatkan diri dengan siswa, 5) mengarahkan siswa dalam melakukan kegiatan pembelajaran berupa keterampilan menanggapi persoalan melihat indikator keterampilan berbicara yang ditentukan,6) mempersiapka lembar observasi untuk guru dan siswa, 7) menciptakan suasana yang menyenangkan pada saat KBM berlangsung.

Pada pelaksanaan tindakan siklus II ini, guru tetap menggunakan model Pembelajaran

Time Token. Pelaksanaan tindkaan siklus II sama dengan pelaksanaan tindakan siklus I pertemuan. Hanya saja pelaksanaan tindakan pada siklus II pertemuan 1 harus lebih di tingkatkan lagi dengan 1) lebih banyak memberikan pentunjuk dan bimbingan pada siswa yang mengalami kesulitan dalam keterampilan berbicara serta mengawasi siswa dan memantau keterampilan siswa dalam berbicara, 2) selama pembelajaran, guru juga memberikan kesempatan dan memotivasi siswa untuk mengeluarkan pendapat secara sistematis dan memberikan kesempatan kepada siswa untuk bertanya serta memberikan pertanyaan secara lisan kepada siswa agar guru mengetahui sejauh mana siswa memahami model Pembelajaran Time Token, 3) memberi kesempatan kepada siswa untuk mengemukakan gagasan dengan bahasa sendiri sesuai dengan materi yang dibahas, 4) memberi kesempatan kepada siswa untuk berpikir tentang kejadian atau peristiwa yang terjadi dalam cerita, 5) memdorong siswa untuk memikirkan perubahan gagasan siswa mengenai peristiwa yang terjadi dengan memberi saran atau tanggapan mengenai peristiwa yang terjadi, 6) menciptakan lingkungan belajar yang menyenangkan, 7) mengamati siswa pada saat proses pembelajaran berlangsung dengan melihat aspek-aspek keterampilan berbicara, 8) melakukan tanya jawab mengenai hal-hal yang belum di pahami/ dimengerti siswa, 9) menyimpulkan materi yang telah disampaikan, 10) menyampaikan kegiatan pembelajaran yang akan dilaksanakan pada pertemuan berikutnya. Berikut ini adalah hasil observasi yang telah dilakukan pada siklus II 
Tabel 3.

Deskripsi Hasil Observasi Siklus II Pertemuan 2

Keterampilan Berbicara Siswa Dalam Kategori

\begin{tabular}{|c|c|c|c|c|c|}
\hline No. & Kriteria & Kategori & $\begin{array}{c}\text { Tingkat } \\
\text { Penguasaan }\end{array}$ & $\begin{array}{l}\text { Jumlah } \\
\text { Siswa }\end{array}$ & Persentase \\
\hline 1. & $\begin{array}{l}\text { Pandangan siswa ketika } \\
\text { berbicara }\end{array}$ & $\begin{array}{l}\text { Sangat Terampi } \\
\text { Terampil } \\
\text { Cukup Terampil } \\
\text { Kurang Terampil }\end{array}$ & $\begin{array}{l}4 \\
3 \\
2 \\
1\end{array}$ & $\begin{array}{c}11 \\
20 \\
4 \\
0\end{array}$ & $\begin{array}{l}31 \% \\
57 \% \\
12 \% \\
0 \%\end{array}$ \\
\hline 2. & $\begin{array}{l}\text { Gerak-gerik mimik siswa } \\
\text { ketika berbicara }\end{array}$ & $\begin{array}{l}\text { Sangat Terampi } \\
\text { Terampil } \\
\text { Cukup Terampil } \\
\text { Kurang Terampil }\end{array}$ & $\begin{array}{l}4 \\
3 \\
2 \\
1\end{array}$ & $\begin{array}{c}12 \\
21 \\
2 \\
0\end{array}$ & $\begin{array}{c}34 \% \\
60 \% \\
6 \% \\
0 \%\end{array}$ \\
\hline 3. & $\begin{array}{l}\text { Keberanian siswa ketika } \\
\text { berbicara }\end{array}$ & $\begin{array}{l}\text { Sangat Terampi } \\
\text { Terampil } \\
\text { Cukup Terampil } \\
\text { Kurang Terampil }\end{array}$ & $\begin{array}{l}4 \\
3 \\
2 \\
1\end{array}$ & $\begin{array}{c}8 \\
23 \\
4 \\
0\end{array}$ & $\begin{array}{l}23 \% \\
65 \% \\
12 \% \\
0 \% \\
\end{array}$ \\
\hline 4. & $\begin{array}{l}\text { Penguasaan topik dalam } \\
\text { pengajaran }\end{array}$ & $\begin{array}{l}\text { Sangat Terampi } \\
\text { Terampil } \\
\text { Cukup Terampil } \\
\text { Kurang Terampil }\end{array}$ & $\begin{array}{l}4 \\
3 \\
2 \\
1\end{array}$ & $\begin{array}{c}13 \\
20 \\
2 \\
0\end{array}$ & $\begin{array}{c}37 \% \\
57 \% \\
6 \% \\
0 \% \\
\end{array}$ \\
\hline 5. & $\begin{array}{l}\text { Ragam bahasa yang } \\
\text { diucapkan ketika } \\
\text { mengemukakan gagasan }\end{array}$ & $\begin{array}{l}\text { Sangat Terampi } \\
\text { Terampil } \\
\text { Cukup Terampil } \\
\text { Kurang Terampil }\end{array}$ & $\begin{array}{l}4 \\
3 \\
2 \\
1\end{array}$ & $\begin{array}{c}9 \\
22 \\
4 \\
0\end{array}$ & $\begin{array}{l}26 \% \\
63 \% \\
11 \% \\
0 \% \\
\end{array}$ \\
\hline 6. & $\begin{array}{l}\text { Pengucapan vocal dan } \\
\text { konsonan }\end{array}$ & $\begin{array}{l}\text { Sangat Terampi } \\
\text { Terampil } \\
\text { Cukup Terampil } \\
\text { Kurang Terampil }\end{array}$ & $\begin{array}{l}4 \\
3 \\
2 \\
1\end{array}$ & $\begin{array}{c}10 \\
23 \\
2 \\
0\end{array}$ & $\begin{array}{c}28 \% \\
66 \% \\
6 \% \\
0 \% \\
\end{array}$ \\
\hline 7. & $\begin{array}{l}\text { Berbicara dengan } \\
\text { mengeluarkan suara yang } \\
\text { nyaring }\end{array}$ & $\begin{array}{l}\text { Sangat Terampi } \\
\text { Terampil } \\
\text { Cukup Terampil } \\
\text { Kurang Terampil }\end{array}$ & $\begin{array}{l}4 \\
3 \\
2 \\
1\end{array}$ & $\begin{array}{c}10 \\
21 \\
4 \\
0\end{array}$ & $\begin{array}{l}28 \% \\
60 \% \\
11 \% \\
0 \%\end{array}$ \\
\hline 8. & $\begin{array}{l}\text { Pengucapan sesuai } \\
\text { dengan tekanan nada dan } \\
\text { irama }\end{array}$ & $\begin{array}{l}\text { Sangat Terampi } \\
\text { Terampil } \\
\text { Cukup Terampil } \\
\text { Kurang Terampil }\end{array}$ & $\begin{array}{l}4 \\
3 \\
2 \\
1\end{array}$ & $\begin{array}{c}10 \\
22 \\
3 \\
0\end{array}$ & $\begin{array}{c}28 \% \\
63 \% \\
9 \% \\
\%\end{array}$ \\
\hline \multicolumn{3}{|c|}{ Jumlah } & & 35 & $100 \%$ \\
\hline
\end{tabular}

Refleksi Siklus II, Keterampilan berbicara siswa pada siklus II pertemuan 1 dan 2 mengalami peningkatan. Pada pertemuan 1 dari 35 orang siswa, sebanyak 29 orang siswa (83\%) yang terampil berbicara dengan rata-rata skor yang diperoleh 75,87 dan pada pertemuan 2 sebanyak 35 orang siswa $(100 \%)$ yang terampil berbicara dengan rata-rata skor 85,75 . Berdasarkan persentase keterampilan berbicara pada siklus II pertemuan 2 sebesar 100\% dapat disimpulkan bahwa peringkat keterampilan berbicara siswa termasuk pada kriteria penilaian sangat terampil. Observasi yang dilakukan terhadap guru diperoleh nilai rata-rata 85,75.. Berdasarkan hasil yang diperoleh pada siklus II, maka tindakan pada siklus selanjutnya tidak perlu dilakukan lagi sebab pada siklus II telah mencapai standar keterampilan berbicara yang telah ditentukan. Keterampilan berbicara siswa secara klasikal pada siklus II dapat dilihat pada tabel di bawah ini: 
Tabel 4

Keterampilan Berbicara Siswa Secara Klasikal Pada Siklus II

\begin{tabular}{|c|c|c|c|c|}
\hline No & Kategori & $\begin{array}{c}\text { Siklus } 2 \text { pertemuan } \\
1\end{array}$ & $\begin{array}{c}\text { Siklus } 2 \text { pertemuan } \\
2 \\
\end{array}$ & $\begin{array}{c}\text { Jumlah } \\
\text { Siswa }\end{array}$ \\
\hline 1 & Siswa Terampil & 29 & 35 & \multirow[t]{3}{*}{35} \\
\hline 2 & Siswa Kurang Terampil & 6 & $\mathbf{0}$ & \\
\hline \multicolumn{2}{|c|}{$\begin{array}{l}\text { Persentase Keterampilan } \\
\text { Berbicara Siswa: } \mathrm{P}=\frac{\boldsymbol{f}}{\boldsymbol{n}} \boldsymbol{x} \mathbf{1 0 0} \%\end{array}$} & $\begin{array}{l}\frac{29}{35} x 100 \% \\
=83 \%\end{array}$ & $\frac{35}{35} \times 100 \%=100 \%$ & \\
\hline
\end{tabular}

\section{Pembahasan Hasil Penelitian}

Penelitian yang dilakukan di SMA Negeri 5 Medan bertujuan untuk mengetahui apakah dengan menggunakan model pembelajaran Time Token dapat meningkatkan keterampilan berbicara siswa pada pelajaran Bahasa Inggris di kelas X. Dari 35 orang siswa, dapat diketahui bahwa keterampilan berbicara siswa pada siklus I pertemuan 1 menunjukkan bahwa keterampilan berbicara siswa pada pelajaran bahasa Indonesia masih sangat rendah, hal itu dapat dilihat pada jumlah siswa yang terampil berbicara hanya 9 orang siswa (26\%) saja, dan 26 orang siswa (74\%) yang kurang terampil berbicara, nilai rata-rata terhadap aktivitas guru yaitu 61,36 . Sedangkan pada siklus I pertemuan 2, dapat dijelaskan bahwa dari 35 orang siswa terdapat 18 orang siswa $(51 \%)$ yang terampil berbicara, dan 17 orang siswa (49\%) yang kurang terampil berbicara, dan nilai rata-rata terhadap aktivitas guru yaitu 65,90 .

Upaya yang dilakukan adalah mengatasi kesulitan-kesulitan dan memperbaiki proses pembelajaran agar keterampilan berbicara siswa lebih meningkat. Di samping itu memperbaiki kondisi pembelajaran dengan cara memotivasi siswa dengan mengajarkan materi yang langsung dari pengalaman siswa agar pelajaran dapat lebih dimengerti oleh siswa.

Pada siklus II pertemuan 1 keterampilan berbicara siswa dalam pelajaran bahasa Indonesia sudah mulai mengalami peningkatan. Pada siklus II pertemuan 1 terdapat 6 orang siswa (17\%) yang terampil berbicara, dan 29 orang siswa (83\%) yang kurang terampil berbicara, nilai ratarata terhadap aktivitas guru yaitu 73,87. Namun, peneliti masih perlu melakukan siklus II pertemuan 2. Pada siklus II pertemuan 2 menunjukkan hasil yang memuaskan yaitu 35 orang siswa (100\%) yang terampil berbicara dan nilai rata-rata terhadap aktivitas guru yaitu 85,75. Hasil observasi yang dilakukan oleh penelti menunjukkan bahwa pembelajaran dengan menggunakan model pembelajaran Time Token sudah bisa dikatakan terampil.

Tabel 5. Rekapitulasi Keterampilan Berbicara siswa pada Siklus I dan II

\begin{tabular}{|c|c|c|c|}
\hline Siklus & Pertemuan & $\begin{array}{c}\text { Jumlah Siswa } \\
\text { yang Terampil }\end{array}$ & $\begin{array}{c}\text { Persentase Keterampilan Berbicara } \\
(\%)\end{array}$ \\
\hline \multirow{2}{*}{ I } & I & $\mathbf{9}$ & $\mathbf{2 6 \%}$ \\
\cline { 2 - 4 } & II & $\mathbf{1 8}$ & $\mathbf{5 1 \%}$ \\
\hline \multirow{2}{*}{ II } & I & $\mathbf{2 9}$ & $\mathbf{8 4 \%}$ \\
\cline { 2 - 4 } & II & $\mathbf{3 5}$ & $\mathbf{1 0 0 \%}$ \\
\hline
\end{tabular}

Dari tabel 5 tersebut maka dapat digambarkan perkembangan keterampilan berbicara siswa kelas X SMA Negeri 5 Medan setelah menggunakan model Time Token mengalami peningkatan yang signifikan. Hal tersebut dapat dilihat dari grafik berikut ini : 


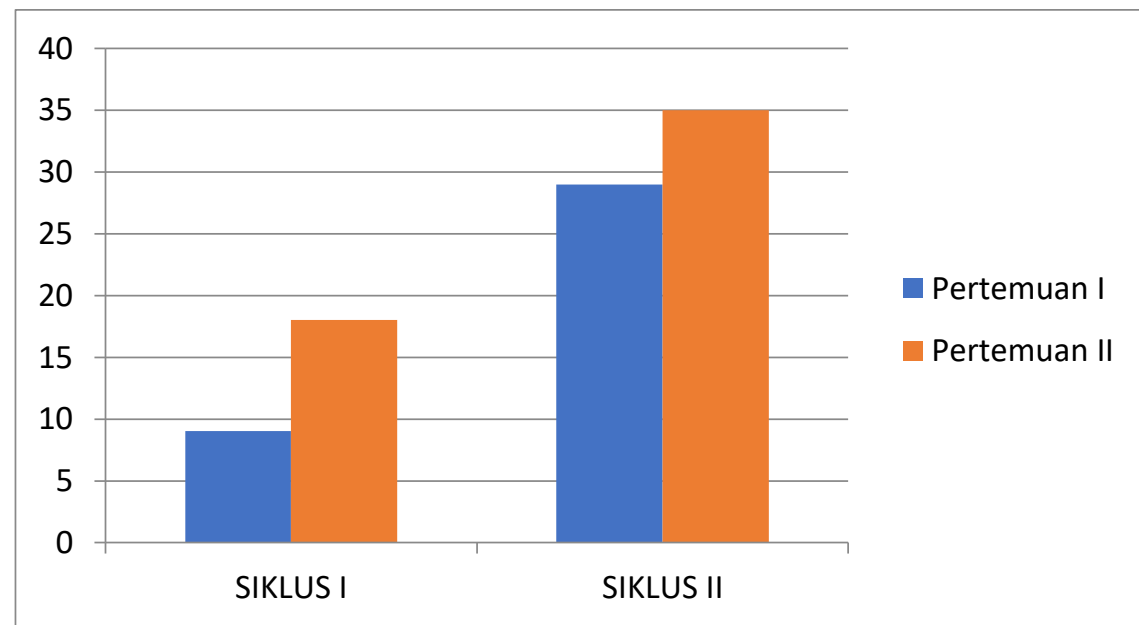

\section{Gambar 1. Grafik Perkembangan Keterampilan Berbicara Siswa dengan Menggunakan Model Pembelajaran Time Token}

Berdasarkan hasil penelitian dan uraian pembahasan di atas dapat diperoleh data bahwa penggunaan model pembelajaran Time Token dapat meningkatkan keterampilan berbicara siswa dalam pembelajaran Bahasa Indonesia secara optimal. Hal ini sejalan dengan hasil penelitian yang sudah dilakukan oleh Yenidar dalam jurnalnya yang menyatakan bahwa "Pembelajaran dengan metode belajar menggunakan model pembelajaran Time Token Arends pada mata pelajaran Bahasa Indonesia memiliki dampak positif dalam meningkatkan kinerja guru yang ditandai dengan peningkatan ketuntasan belajar peserta didik."

Nurwanti dalam jurnalnya juga menyatakan bahwa "Hasil belajar Fisika yang diperoleh siswa kelas X SMA TRIDHARMA MKGR Makassar setelah diajar dengan menggunakan model pembelajaran Time Token telah mencapai KKM yang ditetapkan sekolah. Dengan demikian dapat dikemukakan bahwa dengan Menggunakan model pembelajaran time token merupakan salah satu model pembelajaran Fisika yang dapat digunakan dalam mencapai KKM Standar Sekolah.”

\section{KESIMPULAN}

Dari hasil penelitian dan pembahasan yang ditemukan peneliti, maka dapat diperoleh kesimpulan bahwa dengan menggunakan model pembelajaran Time Token untuk pembelajaran keterampilan berbicara siswa sangat tepat karena dapat menumbuhkan semangat siswa dalam belajar khususnya pada mata pelajaran Bahasa Indonesia materi pokok teks anekdot di kelas $\mathrm{X}$ SMA Negeri 5 Medan. Hal ini dapat dilihat dari hasil pengamatan terhadap kegiatan pembelajaran yang dilakukan mulai dari siklus I pertemuan 1 dan 2 hingga siklus II pertemuan 1 dan 2 terus mengalami peningkatan yang signifikan. Dengan demikian dapat disimpulkan bahwa dengan menggunakan model pembelajaran Time Token dapat meningkatkan keterampilan berbicara siswa pada mata pelajaran bahasa Indonesia pada materi pokok teks anekdot di kelas X SMA Negeri 5 Medan.

Berdasarkan hasil penelitian dan kesimpulan diatas maka peneliti memberikan saran pada semua guru khususnya guru Bahasa Indonesia diharapkan untuk menerapkan model pembelejaran Time Token untuk meningkatkan kualitas keterampilan berbicara siswa karena dengan model pembelajaran Time Token dapat menumbuhkan keberanian bagi siswa untuk mengungkapkan ide pikirannya dan lebih mudah mengingat materi yang sedang dipelajari dengan mengalami langsung.

\section{DAFTAR PUSTAKA}

Arikunto,Suharsimi.dkk. 2015. Penelitian Tindakan kelas. Jakarta : PT Bumi Aksara

Brown,Douglas. 2008. Prisip Pembelajaran Dan Pengajaran Bahas,. Alih bahasa : Noor Cholis dan Yusi Avianto Pareanom. Jakarta : Kedutaan Amerika Serikat 
Huda, Miftahul. 2013. Model-Model Pengajaran dan Pembelajaran Isu-Isu Metodis dan Paradigmatis. Yogyakarta: Pustaka Pelajar

Istarani. 2011. 58 Model Pembelajaran Inovatif. Medan : Media persada

Nurwati. Jurnal Pendidikan Fisika, FKIP, Universitas Muhammadiyah : Penerapan Model Pembelajaran Time Token terhadap Pencapaian Hasil Belajar Fisika kelas X SMA Tridarma MKGR Makasar. Volume I | Nomor 3 | ISSN: 2302-8939| 236 - 243

Sanjaya, Wina. 2010. Strategi Pembelajaran Berorientasi Standar Proses Pendidikan. Jakarta : Kencana Preada Media Grouf

Subhayni,dkk. 2017. Keterampilan Berbicara. Banda Aceh : Syiah kuala University Press.

Suprijono, Agus. 2009. Cooperative Learning Teori dan Aplikasi PAIKEM. Yogyakarta: Pustaka Pelajar.

Suyanto. 2013. Guru Profesional, Strategi Meningkatkan Kualifikasi dan Kualitas Guru di Era Global. Jakarta: Erlangga.

Syah, Muhibbin. 2010. Psikologi Pendidikan dengan pendekatan baru. Bandung : PT Remaja Rosdakary.

Tantawi,Isma.2019. Terampil Berbahasa Indonesa (untuk Perguruan Tinggi). Jakarta : Kencana Trianto.2009. Mendesain Model Pembelajaran Inovatif-Progresif. Jakarta: Kencana

Yenidar. 2017.Jurnal Ilmu Pendidikan Universitas Riau : Penggunaan metode Time Token Arends untuk Meningkatkan keterampilan Berbicara pada Matapelajaran bahasa Indonesia peserta Didik Kelas IV SD Negeri 015 Sungai Rukan . Volume 6 | Nomor 2 | ISSN: 2303-1514 | 430-440 